\title{
The exclusion of hypochromia from the iron deficiency screen
}

\author{
This article was published in the following Dove Press journal: \\ Risk Management and Healthcare Policy \\ 14 March 2014 \\ Number of times this article has been viewed
}

\section{Oscar MP Jolobe}

Manchester Medical Society, Manchester, UK
Correspondence: Oscar MP Jolobe

Manchester Medical Society,

I Philip Godlee Lodge, 842 Wilmslow

Road, Manchester M20 2DS, UK

Tel +44 I6I 4489034

Email oscarjolobe@yahoo.co.uk

\section{Dear editor}

When the screening strategy for iron deficiency makes use of mean corpuscular volume $(\mathrm{MCV})$ to the exclusion of mean corpuscular hemoglobin $(\mathrm{MCH})$, as was the case in the recent study by Radia et al ${ }^{1}$ there is a risk of repeating the mistakes highlighted in a retrospective analysis of the management of anemia, microcytosis, and hypochromia in preoperative subjects in South Australia. ${ }^{2}$

In David et al' $\mathrm{s}^{2}$ retrospective analysis of data from 943 adults, the overall prevalence of anemia was $25.2 \%$, and the median age of the 238 anemic subjects was 73 years old. Among the 238 anemic subjects, the prevalence of hypochromia (characterized by $\mathrm{MCH}<27 \mathrm{pg}$ ) was $19.3 \%$, and the prevalence of microcytosis (characterized by $\mathrm{MCV}<80 \mathrm{fl}$ ) was $5.9 \%$. Among the 705 non-anemic subjects the prevalence of hypochromia and microcytosis was $3.8 \%$ and $1.9 \%$, respectively. ${ }^{2}$ Had the flowchart for the Rapid Access Anemia Patient pathway depicted in Radia et al's Figure $3^{1}$ been followed, none of David et al's ${ }^{2}$ patients with hypochromia (who were in the overwhelming majority) would have been further investigated. In that study, regardless of either MCH or MCV status, none of the 238 anemic patients received the benefit of further investigation; notwithstanding the fact that the study by Jolobe had shown that iron deficiency, when characterized by serum ferritin $<18 \mathrm{mcg} / \mathrm{L}$, was more commonly associated with hypochromia than with microcytosis, and that in some patients (the majority), hypochromia occurred in the absence of microcytosis and, in others (the minority), the opposite was the case. ${ }^{3}$

In the scenario where hypochromia and/or microcytosis coexist with a normal serum ferritin level, the hematological response to a diagnostic trial of intravenous iron replacement therapy could be decisive in validating or refuting a provisional diagnosis of iron deficiency anemia with all that it implies in terms of future management, as depicted in Figure 3. ${ }^{1}$ This is a diagnostic and therapeutic opportunity to be optimized, and this will not happen as long as we continue to perpetuate the notion that iron deficiency is characterized by microcytosis to the total exclusion of hypochromia. ${ }^{4}$

\section{Disclosure}

The author reports no conflicts of interest in this communication.

\section{References}

1. Radia D, Momoh I, Dillon R, et al. Anemia management: development of a rapid access anemia and intravenous iron service. Risk Manag Healthc Policy. 2013;6:13-22. 
2. David O, Sinha R, Robinson K, Cardone D. The prevalence of anemia, hypochromia and microcytosis in preoperative cardiac surgical patients. Anaesth Intensive Care. 2013;41:316-321.

3. Jolobe OM. Prevalence of hypochromia (without microcytosis) vs microcytosis (without hypochromia) in iron deficiency. Clin Lab Haematol. 2000;22:79-80
4. Guyatt GH, Patterson C, Ali M, et al. Diagnosis of iron-deficiency anemia in the elderly. Am J Med. 1990;88:205-209. 


\section{Author's reply}

\section{Deepti Radia}

Haematology Department, Guy's and St Thomas' NHS Foundation Trust, London, UK

Correspondence: Deepti Radia

Haematology Department, 4th Floor, Southwark Wing,

Guy's Hospital, Great Maze Pond, London SEI 9RT, UK

$\mathrm{Tel}+442071882740$

$\mathrm{Fax}+442071882728$

Email deepti.radia@gstt.nhs.uk

\section{Dear editor}

We do look at all the full blood count (FBC) indices and a typical microcytic, hypochromic picture in our South London population is also more than likely to represent a thalassemia/ hemoglobinopathy patient.
The aim of the Rapid-Access Anemia clinic is to detect iron deficiency anemia/hematinic deficiency that can be corrected, and treat the cause - mainly to facilitate surgical intervention in a timely manner.

In patients who have a normochromic anemia - regardless of hypochromasia we would check the hematinics (serum iron, total iron-binding capacity, transferrin saturation, holo-transcobalamin and folate) and this would also uncover any significant iron deficiency. In these days of increasing demand management and decreasing funds we try to follow a pragmatic approach using a complete and thorough clinical history as a guideline to investigation.

\section{Disclosure}

The author reports no conflicts of interest in this communication.

\section{Publish your work in this journal}

Risk Management and Healthcare Policy is an international, peerreviewed, open access journal focusing on all aspects of public health, policy, and preventative measures to promote good health and improve morbidity and mortality in the population. The journal welcomes submitted papers covering original research, basic science, clinical \& epidemio-

logical studies, reviews and evaluations, guidelines, expert opinion and commentary, case reports and extended reports. The manuscript management system is completely online and includes a very quick and fair peerreview system, which is all easy to use. Visit http://www.dovepress.com/ testimonials.php to read real quotes from published authors. 